\title{
Landscape use by cattle affected by pasture developments and season
}

\author{
HAITAO ZUO AND MARY S. MILLER-GOODMAN
}

Authors are former Graduate Research Assistant and Associate Professor, Department of Agronomy and Soils, Auburn University, Auburn, Ala. 36849-5412. Research supported by an Alabama Department of Environmental Management Section 319 Nonpoint Source Program Grant and an Auburn University Dissertation Research Award. The first author's current address is: Beijing Research \& Development Center for Grass and Environment, Beijing Academy of Agriculture and Forestry Sciences, Banjing, Haidian, Beijing 100092, P.R. China.

Abstract

Allowing cattle (Bos taurus L.) unrestricted access to streams can contribute to degradation of riparian and aquatic habitats. The objectives of this study were (1) to quantify the amount of time cattle spend using streams and associated riparian habitats when off-stream water and shade sources are offered and (2) to relate these patterns of habitat use to diurnal and seasonal changes in environmental conditions characteristic of the lower southeast. Diurnal (dawn-to-dusk) patterns of cattle location and behaviors were monitored between March 2000 and October 2001 in north-central Alabama at farms with pastures in which wooded streams were present. No significant decrease was detected in the length of diurnal periods cattle spent in riparian habitats after water and shade developments were in place. Grazing (7.8 hours) dominated daytime behaviors of cattle during the cool season when preference was for grassland habitat (7.6 hours). During the warm season, time spent lying increased to 4.7 hours versus 2.7 hours during the cool season; cattle consistently sought either riparian or other wooded habitat at midday and afternoon in comparison to morning and evening periods. Overall, grazing behaviors occurred predominantly $(80 \%)$ in grassland habitat and lying behaviors occurred mainly (60\%) in wooded habitat. Results suggested that comfort (relief from heat stress) appeared to be a major criterion in habitat use decisions by cattle during the warm season for the relatively small spatial scales (3.3 and 6.9 ha) studied. Therefore, dependence only on water and shade developments for alterations in livestock distribution may not be the most effective strategy for reduced degradation of many riparian habitats found in this region.

Key Words: habitat use, DEI, distribution patterns, riparian habitats, diurnal activities, shade sources, lower southeastern USA, water sources

When cattle have unrestricted access to all habitats within heterogenous landscapes, they usually spend relatively more time in habitat closest to shade and water sources (Blackshaw and Blackshaw 1994, Platts 1991). This behavior has been identified as a source of nonpoint pollution (Martin 1997, Smolen et al. 1990) because it creates a high potential for accumulation of

The authors wish to thank Mr. James Glenn and Mr. Jack Summerford for generously allowing access to their properties. We also thank Mr. Rick Zellmer, GIS Specialist, USDA-NRCS, Auburn, Ala. for assistance with map development.

Manuscript accepted: 29 Feb. 04.

\section{Resumen}

Permitir al ganado (Bos taurus L.) el acceso sin restricciones a las corrientes puede contribuir a la degradación de los hábitats ribereños y acuáticos. Los objetivos de este estudio fueron; (1) cuantificar la cantidad de tiempo que el ganado gasta usando las corrientes de agua y los hábitats ribereños asociados cuando se le ofrece sombra y agua fuera de las corrientes, (2) relacionar estos patrones de uso del hábitat con los cambios diarios y estacionales de las condiciones ambientales climáticas características del bajo sudeste. Los patrones diurnos (del amanecer al atardecer) de localización y comportamiento del ganado se monitorearon entre Marzo del 2000 y Octubre del 2001 en granjas de la región nortecentro de Alabama con potreros en los cuales estaban presentes arroyos con arboles. No se detecto una disminución significativa en la longitud de los periodos diarios que el ganado pasó en los hábitats ribereños después de que colocar sombraderos y aguajes en el lugar. En la estación fría, el apacentamiento (7.8 horas) dominó el comportamiento del ganado durante el día el cual tuvo preferencia por los zacatales (7.6 horas).Durante la estación caliente el tiempo que el ganado pasó echado se incremento de 2.7 horas en la estación fría a $\mathbf{4 . 7}$ horas en la caliente. Al mediodía y en la tarde el ganado busco consistentemente tanto los hábitats ribereños como los arbolados en comparación con la tarde o la noche. En general, el comportamiento de apacentamiento ocurrió predominantemente $(80 \%)$ en el hábitat de zacatal y el comportamiento de echarse ocurrió principalmente $(60 \%)$ en los hábitat arbolado. Los resultados sugieren que el confort (liberarse del estrés del calor) pareció ser el criterio principal para las decisiones de uso del hábitat durante la estación caliente, esto debido a las escalas espaciales relativamente pequeñas (3.3 and 6.9 ha).Por lo tanto depender únicamente en el desarrollo de aguajes y sombreaderos para alterar la distribución del ganado puede no ser la estrategia mas efectiva para reducir la degradación de muchos hábitats ribereños que se encuentran en esta región.

nutrients (Barrow 1987) and bacteria (Pell 1997) in streambank soils, stream water, and stream-bottom sediments (Howell et al. 1995), especially when natural shade and water occur in close proximity. In addition, concentrated loafing in streamside habitats is often detrimental to quantity and diversity of riparian vegetation, stability of stream banks, and hydrologic characteristics of riparian soils (Trimble and Mendel 1995).

Pasture developments are often recommended for reduction or elimination of cattle damage to streams and associated riparian 
areas. Developments that have been proposed to reduce cattle access to streams include: fencing (Bryant 1982, Davis et al. 1991), location of alternative water sources away from streams (Howery et al. 1998, Smith et al. 1992), and construction of artificial shade in upland areas (Howery et al. 1998). However, debate related to economic consequences, management issues and possible regulatory involvement has decreased emphasis on fencing streams over entire watersheds (Sheffield et al. 1997). Studies in the western (Miner et al. 1992, Godwin and Miner 1996) and northeastern USA (Sheffield et al. 1997) have shown that location of water sources off-stream, without additional fencing, can be effective for reduction of cattle impacts to streams and riparian areas associated with pastures in those regions. However, little information is available on the effectiveness of water or shade developments to attract cattle away from streams and riparian areas in the lower portion of the southeast where summers are characterized by both elevated air temperature and relative humidity.

The objectives of this study were (1) to quantify the amount of time beef cattle spend using streams and associated riparian habitats that bisect pastures when off- stream water and shade developments are offered in the same landscape and (2) to relate these patterns of habitat use to diurnal and seasonal changes in environmental conditions characteristic of the lower southeast. The hypothesis was that alternative water sources alone would not be sufficient to attract cattle away from riparian habitats in these environments and that construction of artificial shade in combination with water development would be necessary to significantly decrease the attraction of cattle to these sensitive landscape areas.

\section{Materials and Methods}

\section{Description of Study Areas}

The project was conducted near the town of Danville, Ala., USA $(182.9 \mathrm{~m}$, $34^{\circ} 25^{\prime} \mathrm{N}, 87^{\circ} 05^{\prime} \mathrm{W}$ ) at Glendale Farms, Lawrence County, Ala. and Summerford Farms, Morgan County, Ala. (Fig. 1). A second order stream (Sheats Branch) was located in the landscape studied at Glendale Farms and a third order stream (Crowdabout Creek) bisected the landscape at Summerford Farms; cattle (Bos taurus L.) were allowed unrestricted access to the streams at each farm. The landscape studied at Glendale Farms was within a 3.3-ha pasture (Fig. 1 A); at Summerford Farms the pasture was 6.9-ha (Fig. 1B). Both landscapes were subunits of rotational stocking systems at each farm. Three habitat types were defined within the landscapes studied at each farm: riparian (stream $+10-m$ wooded buffer from each streambank), grassland (open pasture area), and wooded (woods outside 10-m wooded riparian buffers). The ratio of different habitat types was approximately 6 (grassland): 1.6 (riparian): 1 (wooded) for both landscapes studied. Ground cover composition of grassland and both overstory and understory cover of riparian and wooded habitats was estimated using a Cover-Point Optical Projection Device (Model 5, ESCO Associates Inc:; Buckner 1985; Table 1). The grassland habitat at each farm was evenly subdivided into 6 areas and one, 1$\mathrm{m}^{2}$ utilization cage was randomly located in each area for estimation of forage production and utilization. Relocation of a cage after clipping was random but as close as possible to the initial cage location so that each cage consistently represented a defined area in the grassland habitats. Measurements indicated uniform forage production and utilization within the grassland habitat at each farm (Zuo 2001).

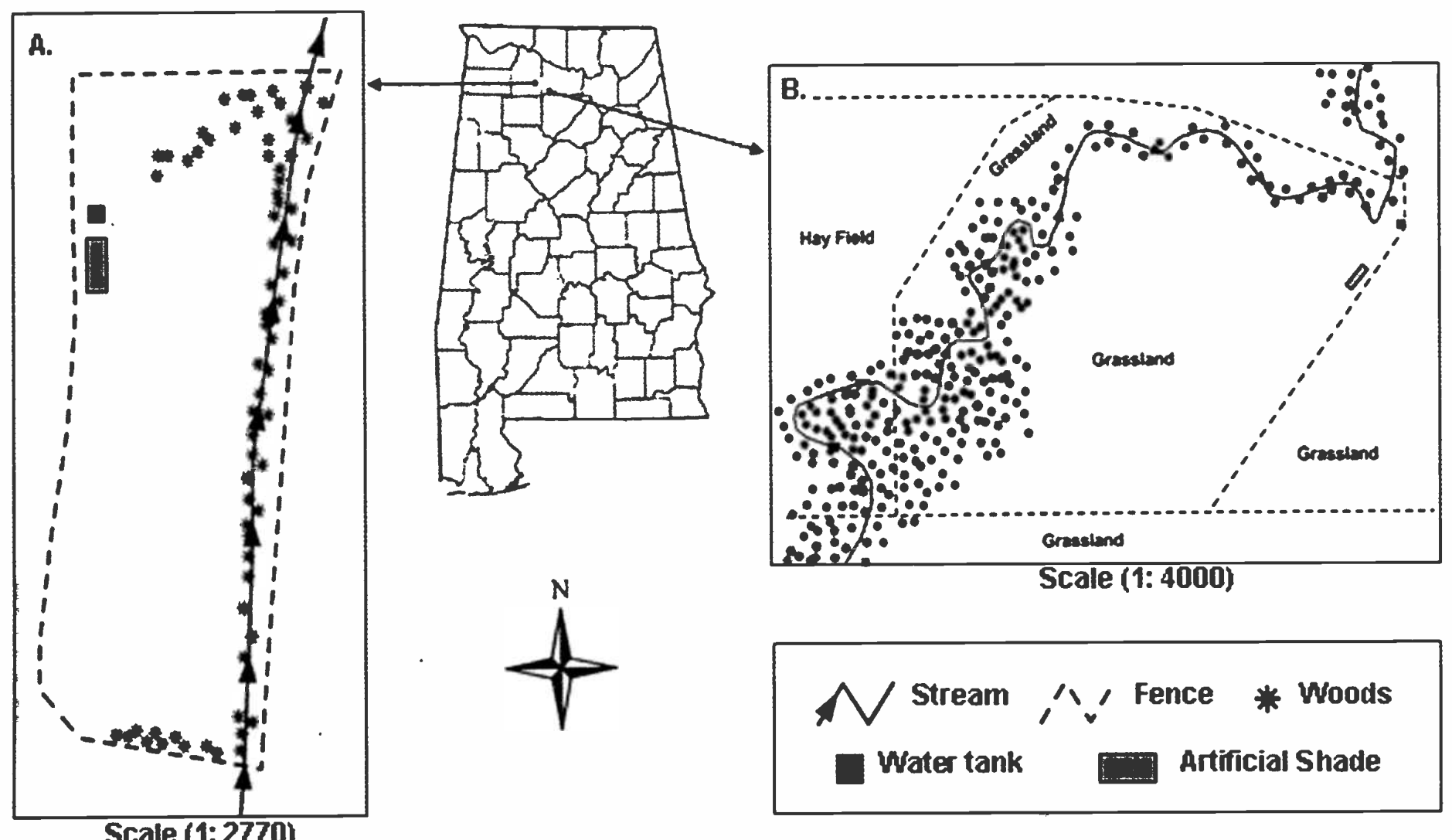

Fig. 1. Landscape features of pastures used for observations of cattle behavior at (A) Glendale Farms, Lawrence County and (B) Summerford Farms, Morgan County, Ala., Mar. 2000 to Oct. 2001. 
Table 1. Seasonal variation for average cover components of grassland and riparian habitats of grazed landscapes at Glendale and Summerford Farms, north-central Alabama 2000-2001.

\begin{tabular}{|c|c|c|c|c|c|c|c|c|c|c|c|c|c|c|}
\hline \multirow{4}{*}{ Season } & \multicolumn{6}{|c|}{ Grassland habitat } & \multicolumn{8}{|c|}{ Riparian habitat } \\
\hline & \multirow{3}{*}{$\begin{array}{l}\text { Bare' } \\
\text { ground }\end{array}$} & \multirow{3}{*}{ Litter $^{2}$} & \multirow{3}{*}{$\begin{array}{c}\text { Total } \\
\text { vegetation }\end{array}$} & \multirow{2}{*}{\multicolumn{3}{|c|}{ Dominant vegetation }} & \multicolumn{2}{|c|}{ Overstory } & \multicolumn{6}{|c|}{ Understory } \\
\hline & & & & & & & \multirow{2}{*}{$\begin{array}{l}\text { Total } \\
\text { cover }\end{array}$} & \multirow{2}{*}{$\begin{array}{l}\text { Dominant } \\
\text { woody } \\
\text { species }^{5}\end{array}$} & \multirow{2}{*}{$\begin{array}{l}\text { Bare' } \\
\text { ground }\end{array}$} & \multirow{2}{*}{ Litter ${ }^{2}$} & \multirow{2}{*}{$\begin{array}{c}\text { Total } \\
\text { vegetation }\end{array}$} & \multicolumn{3}{|c|}{ Dominant vegetation } \\
\hline & & & & Forage $^{3}$ & Forbs & Other ${ }^{4}$ & & & & & & $\begin{array}{c}\text { Tall } \\
\text { fescue }\end{array}$ & Forbs & Other ${ }^{4}$ \\
\hline \multicolumn{14}{|c|}{ Glendale Farms } & ---- \\
\hline $\begin{array}{l}\text { Cool } \\
(n=2)\end{array}$ & 9.2 & 58.5 & 32.3 & $\begin{array}{c}\text { Tall } \\
\text { fescue, } \\
94.7\end{array}$ & 4.0 & 1.3 & 48.0 & $\begin{array}{c}\text { Cedar, } \\
86.7\end{array}$ & 12.2 & 74.5 & 9.4 & 48.8 & 0.0 & 51.2 \\
\hline $\begin{array}{l}\text { Warm } \\
(n=2)\end{array}$ & 2.3 & 40.9 & 56.8 & $\begin{array}{l}\text { Tall } \\
\text { fescue, } \\
61.2\end{array}$ & 15.4 & 23.4 & 83.7 & $\begin{array}{c}\text { Sycamore, } \\
36.2 \\
\text { Oaks, } \\
23.3\end{array}$ & 26.4 & 36.7 & 36.9 & 44.9 & 31.6 & 23.5 \\
\hline \multicolumn{15}{|c|}{ Summerford Farms } \\
\hline $\begin{array}{l}\text { Warm } \\
(n=2)\end{array}$ & 1.7 & 60.1 & 38.2 & $\begin{array}{c}\text { Dallis- } \\
\text { grass, } \\
43.8 \\
\text { Bermuda- } \\
\text { grass, } \\
44.1\end{array}$ & 4.0 & 8.1 & 97.8 & $\begin{array}{c}\text { Box elder, } \\
25.9 \\
\text { Oaks, } \\
19.2\end{array}$ & 57.5 & 35.0 & 7.8 & 4.6 & 81.5 & 13.9 \\
\hline
\end{tabular}

Includes cover by gravel, stone, or surface water.

2 Includes both woody and herbaceous plant litter.

${ }^{3}$ Tall fescue = Festuca arudinacea $($ L.) with $99 \%$ endophyte-infection; dallisgrass = Paspalum dilitatum (Poiret); bermudagrass = Cynondon dactylon (L.)

${ }^{4}$ Other includes: grasses other than tall fescue, dallisgrass or bermudagrass; sedges (Cyperus $\mathrm{sp}$.), rushes (Carex $\mathrm{sp}$.), low woody vegetation, and pteridophytes.

${ }^{5}$ Cedar = Juniperus virginiana $($ L.); sycamore = Platanus occidentalis (L.) Oaks = Quercus sp.; box elder $=$ Acer negundo $(\mathrm{L})$.

A Freedom Fountain ${ }^{\mathrm{TM}}$ 2FC water tank (Behlen Country, Columbus, Neb.) and artificial shade structure were installed in the grassland habitat of the pasture studied at each farm (Fig 1). Pasture development treatments were water tank alone and water tank plus artificial shade. Each water tank was located on a heavy use pad constructed with geotextile fabric covered with crushed stone (NRCS 1999). The frame of the shade structure was $15 \mathrm{~m} \mathrm{x}$ $7.5 \mathrm{~m}$ (3.2-cm pipe) and $3.6 \mathrm{~m}$ high (5.1$\mathrm{cm}$ pipe) (NRCS 2002); ultra-violet-protected polypropylene with an $80 \%$ shade level was used to cover the structure. At Glendale Farms, water and shade dévelopments were located within $25 \mathrm{~m}$ of each other and as far as possible from the wooded riparian area at the highest elevation $(198 \mathrm{~m})$ in the pasture (Fig. 1A). Location of the water development installed at Summerford Farms was based on both highest elevation ( $177 \mathrm{~m}$ ) and ease of accessibility to the site via a gravel lane. Even though this positioned the water tank relatively close to Crowdabout Creek (Fig. 1B), the tank was located as far as possible from the portion of the wooded riparian area (southwest corner of pasture) that was used most consistently by cattle for resting (Zuo 2001). The shade structure at Summerford Farms was located about $50 \mathrm{~m}$ southwest of the water tank.

\section{Observation of Cattle Behaviors}

Experimental periods for analysis of observations of cattle behavior at each farm were based on the date of installation of the pasture developments (Table 2). Diurnal (first light to dark) observations of cattle behavior were made in March and October (cool season) and May, July, and August (warm season) at Glendale Farms in both 2000 and 2001; stocking density during observation periods averaged $5 \mathrm{AU}$ $\mathrm{ha}^{-1}$ during the cool season and $4 \mathrm{AU} \mathrm{ha}^{-1}$ during the warm season. Stocking density was $4 \mathrm{AU} \mathrm{ha}^{-1}$ during observations at Summerford Farms. Observations were made only during the warm season (May, July, and August) at the Summerford location because cattle were usually excluded from the landscape during the cool season since warm-season grasses were dormant.
Temperature and precipitation during the observation periods are summarized in Figure 2.

Observations of cattle behavior were conducted from daybreak to dark at 15 min intervals with the assistance of binoculars from a point that avoided disturbance of cattle. The total diurnal period was divided into morning (dawn to 1100 hours), midday ( 1100 to 1300 hours), afternoon ( 1300 to 1700 hours), and evening ( 1700 hours to dusk) periods. Behaviors of individual animals were categorized as grazing, lying, and loafing. Grazing represented times when cattle were harvesting and masticating forages; lying represented times when cattle were lying down at a given location; loafing represented behaviors other than grazing and lying, such as moving, standing, scratching, and playing. The location, numbers, and behavior categories of each animal were recorded on a landscape map for each 15-min interval during the observation periods; those maps were referred to as distribution plots. For each 15-min distribution plot recorded, the total land- 


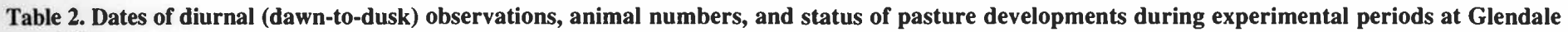
and Summerford Farms, north-central Ala, Jan. 2000 to Dec. 2001.

\begin{tabular}{|c|c|c|c|c|c|}
\hline \multirow[t]{2}{*}{ Experimental period } & \multirow[t]{2}{*}{ Observation dates } & \multicolumn{2}{|c|}{ Animal numberst } & \multicolumn{2}{|c|}{ Status of pasture developments } \\
\hline & & Cows & $\overline{\text { Calves }}$ & Water tank & Artificial shade \\
\hline \multicolumn{6}{|l|}{ Glendale Farms } \\
\hline \multirow{3}{*}{ Jan. - Jun. 2000} & 9 Mar. & 18 & 8 & Not present & Not present \\
\hline & $10 \mathrm{Mar}$. & 18 & 8 & Not present & Not present \\
\hline & 22 May & 14 & 1 & Not present & Not present \\
\hline \multirow[t]{3}{*}{ Jul. - Dec. 2000} & $18 \mathrm{Jul}$. & 15 & 0 & Installed & Not present \\
\hline & 15 Aug. & 12 & 4 & Installed & Not present \\
\hline & 17 Oct & 14 & 9 & Installed & Not present \\
\hline \multirow[t]{5}{*}{ Jan. - Dec. 2001} & 24 Mar. & 8 & 0 & Installed & Installed \\
\hline & 24 May & 17 & 0 & Installed & Installed \\
\hline & 20 July & 22 & 0 & Installed & Installed \\
\hline & 27 Aug. & 22 & 0 & Installed & Installed \\
\hline & 17 Oct. & 21 & 0 & Installed & Installed \\
\hline \multicolumn{6}{|l|}{ Summerford Farms } \\
\hline \multirow[t]{3}{*}{ Jan. - Dec. 2000} & 23 May & 18 & 17 & Installed & Not present \\
\hline & 19 July & 20 & 4 & Installed & Not present \\
\hline & 16 Aug.. & 22 & 5 & Installed & Not present \\
\hline \multirow[t]{3}{*}{ Jan. - Dec. 2001} & 25 May & 18 & 6 & Installed & Installed \\
\hline & $25 \mathrm{Jul}$. & 24 & 0 & Installed & Installed \\
\hline & 28 Aug. & 22 & 0 & Installed & Installed \\
\hline
\end{tabular}

†All animals = Bos taurus L.; Glendale Farms = Hereford; Summerford Farms = mixed commercial herd

scape area was subdivided into zones; the zones in which the alternative water tank or artificial shade structure were installed were identified as 'water tank' or 'artificial shade' zones. Total number of animals and their individual behavior categories were summarized for all zones within each habitat type and observation period. These summaries were used to calculate the Distribution Evenness Index (DEI; Zuo and Miller-Goodman 2003) which described cattle distribution patterns over grassland zones and the whole landscape at each farm:

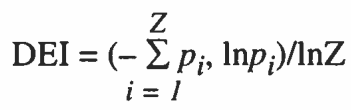

where $p_{i}=$ the proportion of total number or behavioral categories of beef cattle in the ith zone;

$\mathrm{Z}=$ total number of zones studied.
Analysis of variance (PROC GLM, SAS ${ }^{\circledR}$ version 6.12) and Fisher's protected least significant difference (LSD) were used to detect overall differences in habitat use and DEI within different experimental periods as well as diurnal and seasonal patterns of habitat use and behaviors within each farm landscape. Statistical significance was accepted at $\mathrm{P} \leq 0.05$.

\section{$\triangle$ Mean Maximum Daily Temp. - - Mean Minimum Daily Temp. Precipitation}

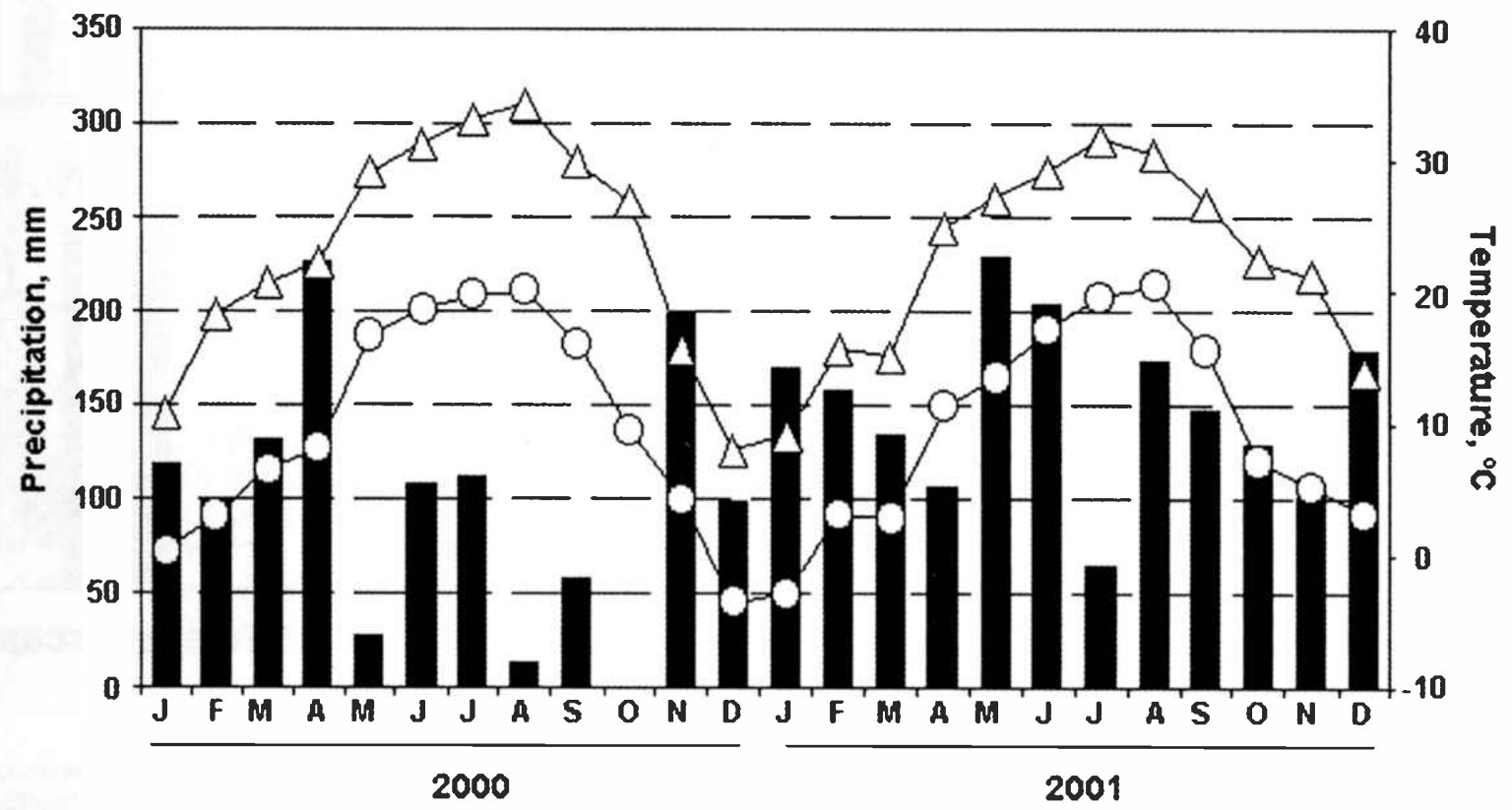

Fig. 2. Monthly mean maximum and minimum daily temperature and monthly precipitation, north-central Ala., Jan. 2000 to Oct. 2001. 

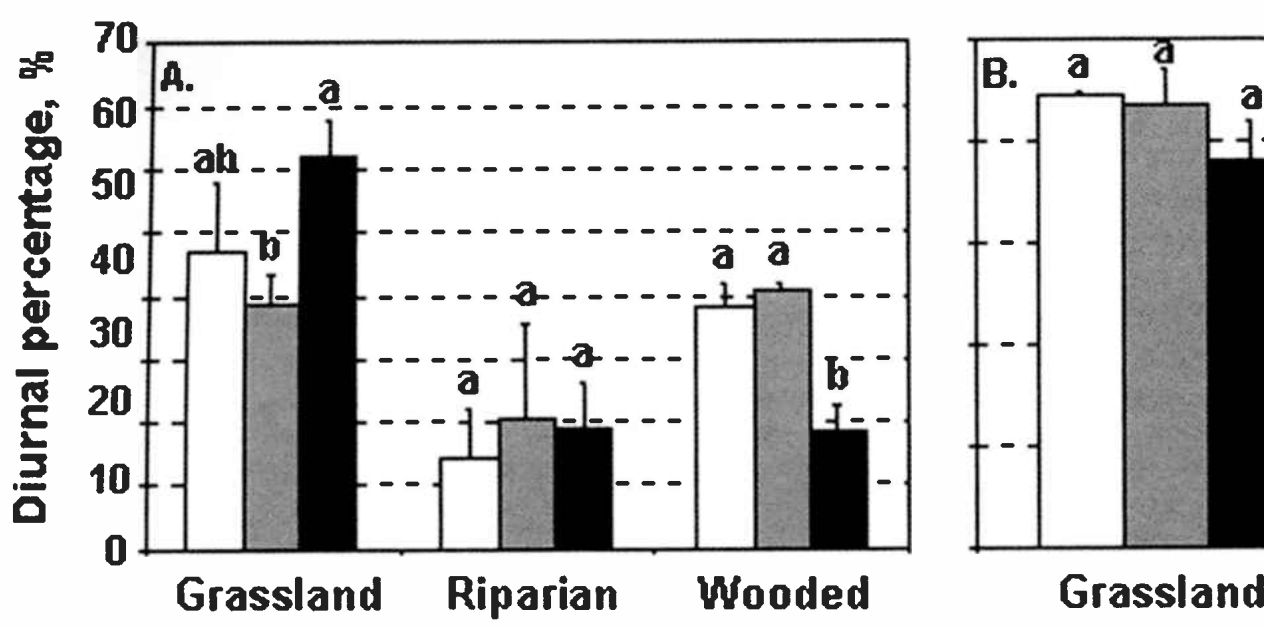

\section{Habitat type}

Fig. 3. (A) Diurnal habitat use by cattle and (B) distribution evenness during experimental periods: Jan. to Jun. 2000 (no developments); Jul. to Dec. 2000 (+water tank); Jan. to Dec. 2001 (+water tank, +artificial shade), Glendale Farms, north-central Ala. Means with same letter are not significantly different within each habitat type or the whole landscape $(P>0.05)$.

\section{Results}

\section{Cattle Response to Pasture \\ Developments}

Water and shade developments did not significantly change percentage of daytime cattle spent in riparian habitats when compared across experimental periods at either Glendale (Fig. 3A) or Summerford (Fig. 4A) Farms. However, cattle spent less daytime $(P \leq 0.05)$ in wooded habitat at Glendale Farms after both water and shade developments were installed (Fig.
3A). There were no significant changes detected for habitat use by cattle in grassland or wooded habitats at Summerford Farms (Fig. 4A). No significant changes in cattle distribution evenness were detected in either grassland habitats or the whole landscape at either farm in response to alternative water or shade sources (Fig. 3B, 4B). Also, the percentage of daytime that cattle spent in the immediate vicinity of water or shade developments did not significantly change among experimental periods within either farm (Table 3 ).

\section{Seasonal Patterns of Diurnal \\ Habitat Use}

Throughout the study at Glendale Farms, cattle preferred $(\mathrm{P} \leq 0.05)$ grassland habitat (7.6 hours) to wooded habitat (3.8 hours) and rejected riparian habitat (1.6 hours) during the cool season, although no habitat preference was detected during midday periods (Fig. 5A). On the contrary, during the warm season, cattle used wooded areas more $(\mathrm{P} \leq 0.05)$ during midday and afternoon compared to evening periods, cattle consistently sought riparian habitats throughout midday and

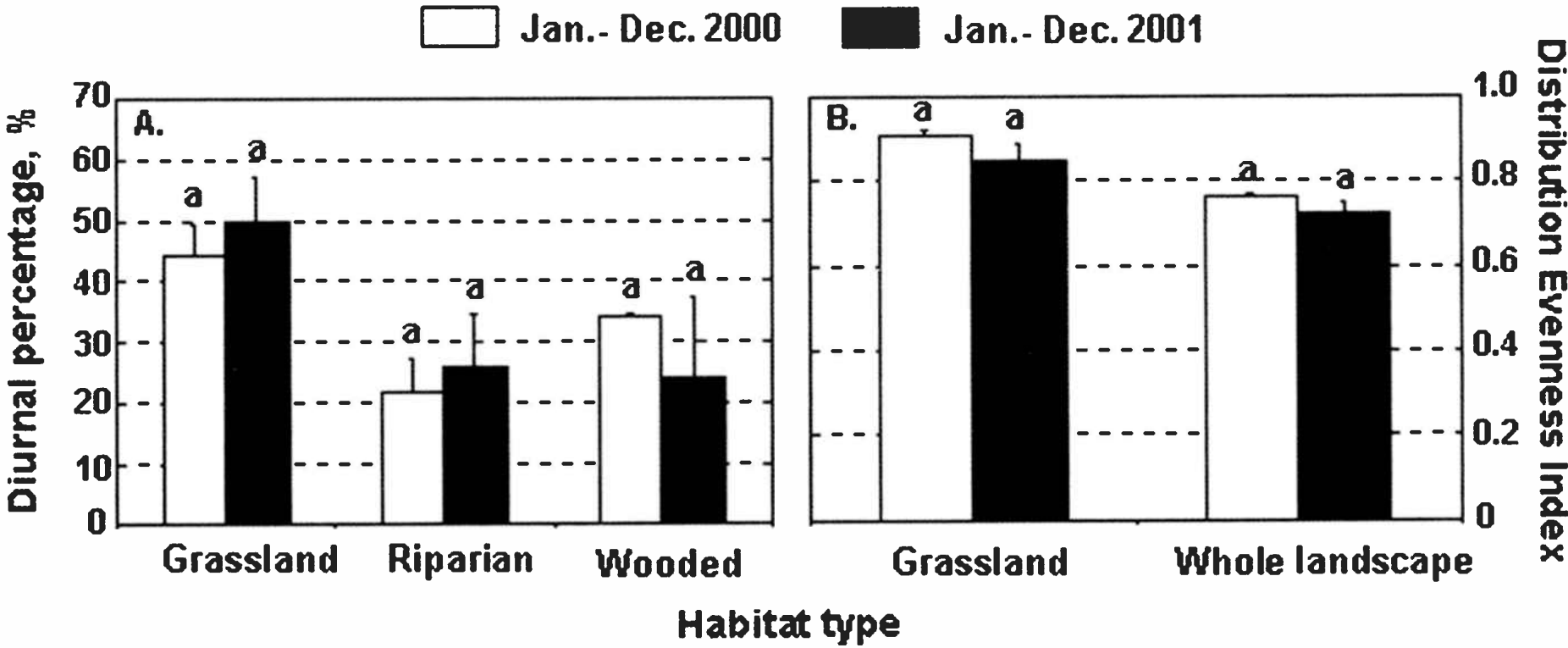

Fig. 4. (A) Diurnal habitat use by cattle and (B) distribution evenness during experimental periods: Jan. to Dec. 2000 (+water tank); Jan. to Dec. 2001 (+water tank, + artificial shade), Summerford Farms, north-central Ala. Means with the same letter are not significantly different within each habitat type or the whole landscape $(P>0.05)$. 
Table 3. Percentage of daytime cattle spent in the vicinity of water and shade developments during/different experimental periods at Glendale and Summerford Farms, north-central Ala., Jan. 2000 to Dec. 2001.

\begin{tabular}{|c|c|c|c|c|c|}
\hline \multirow[b]{2}{*}{ Zone } & \multicolumn{3}{|c|}{ Glendale Farms } & \multicolumn{2}{|c|}{ Summerford Farms } \\
\hline & $\begin{array}{l}\text { Jan.-Jun. } \\
2000\end{array}$ & $\begin{array}{c}\text { Jul.-Dec. } \\
2000\end{array}$ & $\begin{array}{c}\text { Jan.-Dec. } \\
2001\end{array}$ & $\begin{array}{c}\text { Jan.-Dec. } \\
2000\end{array}$ & $\begin{array}{c}\text { Jan.-Dec } \\
2001\end{array}$ \\
\hline & \multicolumn{3}{|c|}{ - } & \multicolumn{2}{|c|}{ - } \\
\hline Water tank & $3.93 \mathrm{a} \dagger$ & $4.34 \mathrm{a}$ & $5.59 \mathrm{a}$ & $1.97 \mathrm{a}$ & $2.22 \mathrm{a}$ \\
\hline Artificial shade & $0.88 \mathrm{a}$ & $0.55 \mathrm{a}$ & $1.73 \mathrm{a}$ & $0.64 a$ & $0.74 \mathrm{a}$ \\
\hline Water tank + artificial shade & $4.81 \mathrm{a}$ & $4.88 \mathrm{a}$ & $7.32 \mathrm{a}$ & $2.61 \mathrm{a}$ & $2.97 \mathrm{a}$ \\
\hline
\end{tabular}

$\doteqdot$ Means with same letter are not significantly different within each farm and row $(\mathrm{P}>0.05)$.

afternoon in comparison to morning and evening periods (Fig. 5C), and use of grassland habitat dominated $(\mathrm{P} \leq 0.05)$ during morning and evening periods. However, when based on total daytime observations, no significant habitat preference was detected during the warm season; times spent in each habitat were: grassland 6.4 hours, wooded 4.3 hours, and riparian 3.3 hours.
At Summerford Farms, use of wooded habitat dominated $(\mathrm{P} \leq 0.05)$ midday compared to the evening period (Fig. 5E) while diurnal habitat use patterns during other daytime periods were similar to those observed at Glendale Farms during the warm season. However, when based on total daytime (Fig. 5E), cattle spent more time $(P \leq 0.05)$ in grassland $(6.7$ hours) than wooded (4.0 hours) or riparian (3.3 hours) habitat.

\section{Seasonal Patterns of Diurnal}

\section{Behaviors}

Grazing behavior dominated $(\mathrm{P} \leq 0.05)$ activities during the total daytime period regardless of season or farm (Fig. 5B, D, F). At Glendale Farms, grazing behavior dominated $(\mathrm{P} \leq 0.05)$ morning, afternoon, and evening periods during the cool season while the remainder of daytime was split between lying and loafing (Fig. 5B). During the warm season, most grazing behavior occurred in morning and evening periods and cattle spent more time lying during midday and afternoon periods (Fig. 5D). Cattle spent less total daytime grazing during the warm season compared to the cool season (6.7 hours versus 7.8 hours), time spent lying increased (4.7 hours versus 2.7 hours), and time spent loafing was similar (2.5 hours versus 2.6 hours).

Distribution of cattle behaviors observed at Summerford Farms were similar to patterns recorded during the warm season at Glendale Farms, although lying dominated midday and afternoon periods to a signifi-

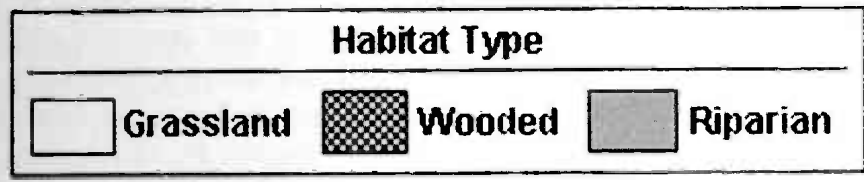

GLENDALE FARMS

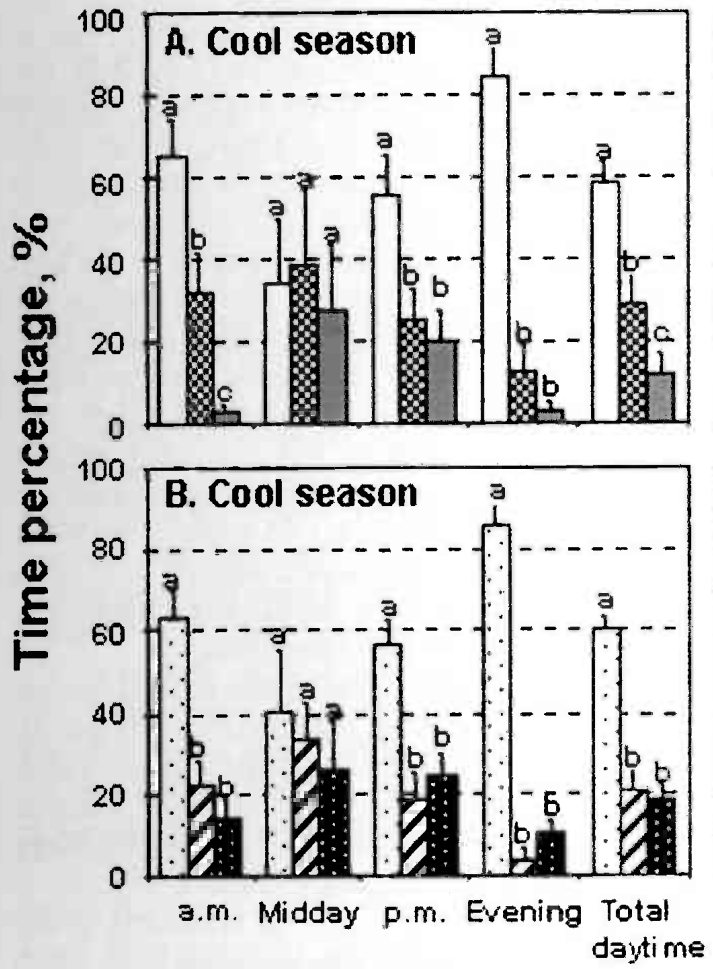

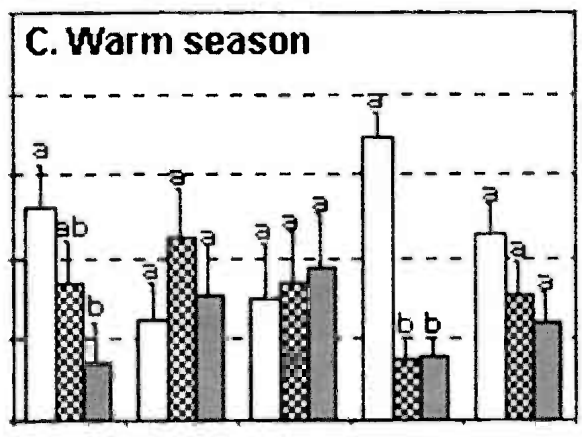

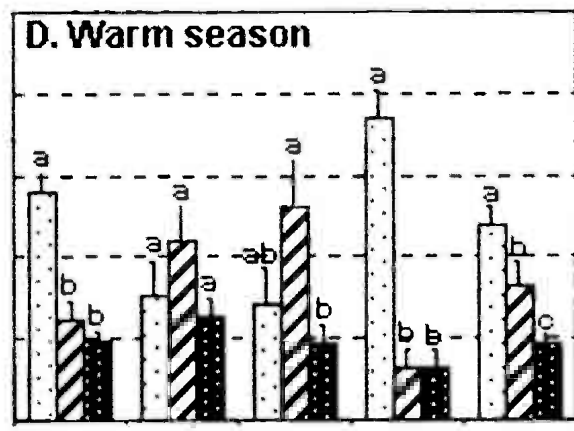

a.m. Midday P.m. Evening Total daytime

\section{Behavior Type} Grazing Ulatying

SUMMERFORD FARMS
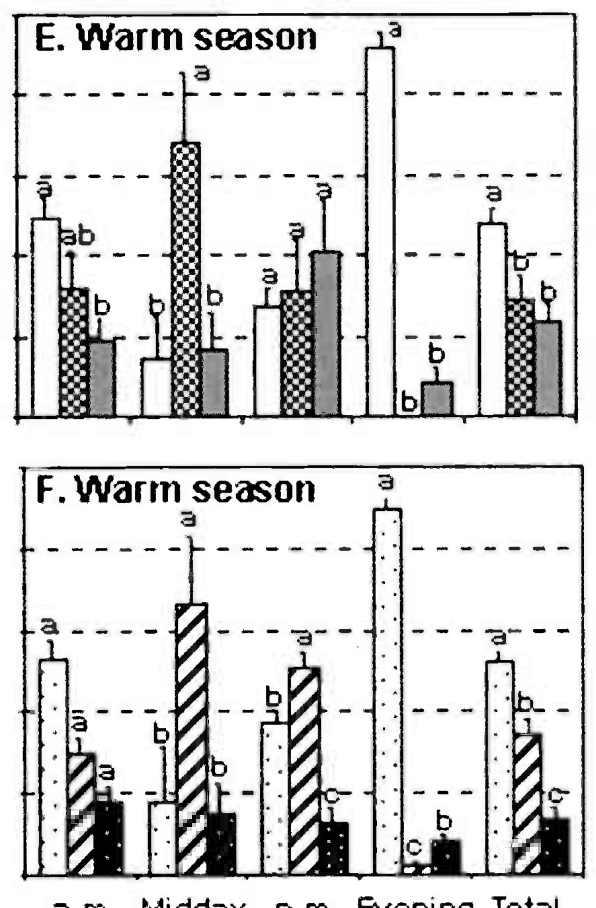

a.m. Midday p.m. Evening Total daytime

\section{Diurnal period}

Fig. 5. Diurnal habitat use and behavior patterns of cattle during cool (A, B) and warm (C, D) seasons at Glendale Farms and during the warm (E, F) season at Summerford Farms, Mar. 2000 to Oct. 2001. Bars with the same letter are not significantly different for a specific diurnal period within a given season and farm $(P>0.05) ;$ a.m. $=$ morning, p.m. $=$ afternoon. 


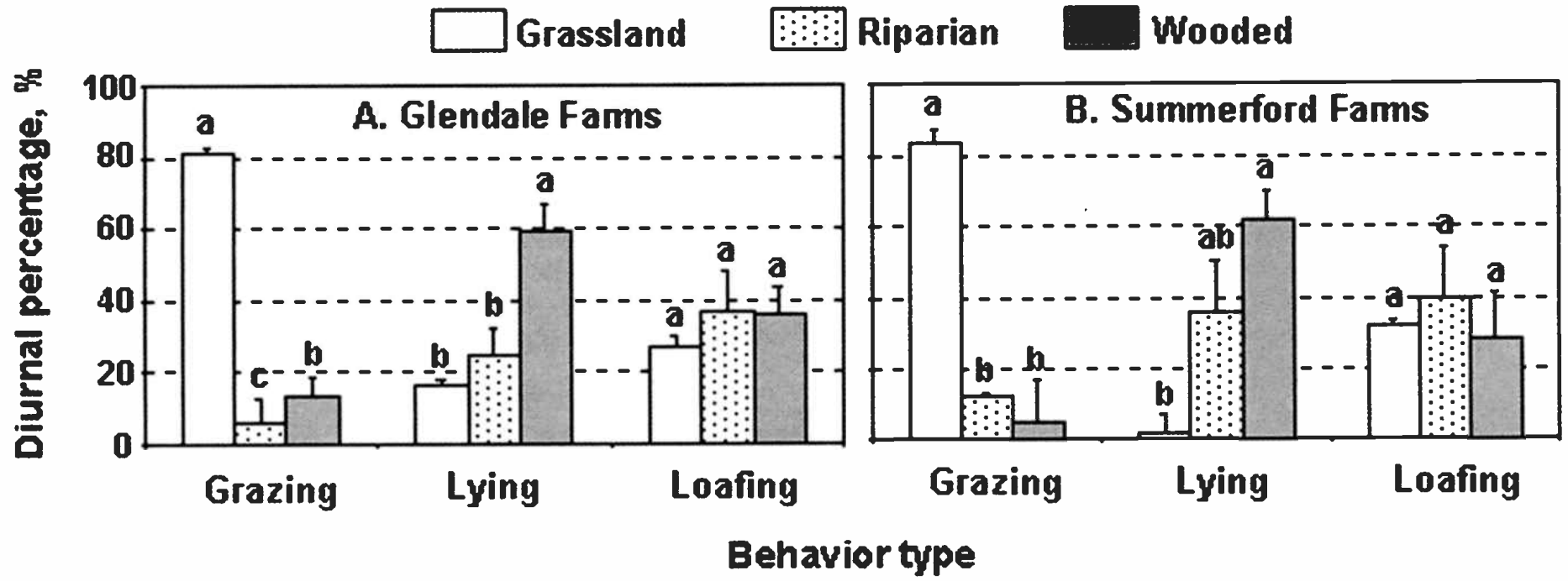

Fig. 6. Mean habitat preference by cattle for grazing, lying and loafing behaviors over all observations at (A) Glendale Farms and (B) Summerford Farms, Mar. 2000 to Oct. 2001. Means with the same letter are not significantly different within each behavior type and farm ( $P>0.05)$.

cant $(\mathrm{P} \leq 0.05)$ degree (Fig. 5F). Total times spent for each behavior at Summerford Farms were: grazing 7.3 hours, lying 4.8 hours, and loafing 1.9 hours.

\section{Diurnal Choice of Behavior \\ Location}

Throughout the study, grazing occurred mainly ( $\mathrm{P} \leq 0.05$ ) in the grassland habitats and seldom in riparian or wooded habitats at either farm (Fig. 6A, B). Lying occurred more often $(P \leq 0.05)$ in wooded habitats, while cattle seldom lay down in grassland habitats. No significant differences were detected for cattle location choice for loafing.

\section{Discussion}

\section{Habitat Use}

Mean daily maximum temperatures were consistently above $25^{\circ} \mathrm{C}$ (Fig. 2) from May to September during both years of observations; $25^{\circ} \mathrm{C}$ is considered the heat stress threshold that coincides with declines in feed intake by livestock (Hahn 1999). In addition to the contribution that elevated air temperatures made to heat stress, cattle at Glendale Farms probably experienced additional heat stress since their diet included endophyte-infected tall fescue (Ball et al. 2002, West 1999). In response to heat stress, the total diurnal time cattle spent grazing declined and lying increased during the warm season (Fig. 5). In addition, seasonal patterns of habitat use revealed that no habitat preference was detected during the warm sea- son, but cattle preferred grassland to both wooded and riparian habitats during the cool season (Fig. 5).

Southwood (1977) pointed out that resource-use patterns of animals are 'trade-offs', a consequence of cost versus benefit in the process of adaptation to habitats, which in turn determine the fitness of various habitats. Riparian habitats are often associated with higher availability of succulent forage than the remainder of the associated pasture or allotment to which cattle have access, especially in arid areas (Bryant 1982, Kauffman and Krueger 1984). In our study, understory forage availability was low in riparian compared to pasture habitat during the warm season at both Glendale and Summerford Farms (Table 1). However, the common characteristic of riparian and wooded habitats during summer at both farms was 'high-quality' shade from large trees, i.e. shade that provided both protection from sunlight and evaporative cooling as water evaporated from the canopy (Blackshaw and Blackshaw 1994). Thus, cattle consistently sought these areas to relieve heat stress during midday and afternoon periods (Fig. 5C, E).

Water availability is another factor that draws cattle to riparian habitats (Bryant 1982). However cattle in the landscapes we studied could quickly satisfy their water requirement (Rouda et al. 1994) with a single drink from either the stream or water tank. Although cooled drinking water such as that on offer at the water tanks can reduce the heat load of cattle by about $3000 \mathrm{~kJ} /$ day, Ittner et al. (1951) pointed out that water helped very little in comparison to the $1400 \mathrm{~kJ} / \mathrm{h}$ heat load reduction achievable through shading. Thus, it appears that increased preference for wooded and riparian habitats by cattle noted in our study during the warm season was driven mainly by requirements for shade to reduce heat loads, not for forage or water.

Although the artificial structures used in this study provided shade of $>3.5 \mathrm{~m}^{2}$ per head and were thought to provide effective protection from heat stress (Mader et al. 1997), no preference for the artificial shade was detected (Table 3). Consequently, there was not a significant reduction in the time cattle spent in riparian habitats when water and shade developments were present (Fig. $3 \mathrm{~A}, 4 \mathrm{~A})$. These observations indicate that if access to natural shade is available, the likelihood appears low that using alternative water sources alone or in combination with artificial shade will significantly lower cattle use, and potential impacts to wooded riparian areas, in similar-sized landscapes and microclimatic conditions.

It has been reported that cattle associate habitat locations with quantity and quality of food available (Bailey et al. 1989, Bailey and Sims 1998). However, because of the spatial and temporal heterogeneity of grazed landscapes, the herbivore is faced with a series of tradeoffs about which habitat to choose (Senft et al. 1987) and habitat selection likely reflects a multitude of life cycle requirements for an animal, not simply feed quantity and quality (Mysterud et al. 1999). Data from this study indicated that grassland habitat was 
selected by cattle mainly for grazing and wooded habitat mainly for resting (lying) and no habitat preference was detected for loafing (Fig. 6). This location choice pattern supports the opinion of Mysterud and Ims (1998) that habitat preference may be conditioned by availability of resources needed to fulfill animal nutritional or comfort requirements. The seasonal patterns of habitat use and behavior detected by this study, especially increased presence in wooded and riparian habitats and dominance of lying behaviors by cattle during midday and afternoon periods during the warm season, also support Van Horne's (1983) opinion that different habitat types may be preferred by animals at different times. In our study, shade accessibility appeared to be the overriding factor in habitat selection and use during daytime in the warm season.

\section{Effect of Scale}

Habitat selection is a scale-dependent process (Johnson 1980, Levin 1992) because different mechanisms and tradeoffs may control an animal's resource use at different spatial and temporal scales. Therefore, integration of processes at various scales is necessary to extrapolate observations from one level of scale to another (Turner et al. 1989). This study was conducted at relatively small spatial scales (3.3 to $6.9 \mathrm{ha}$ ) which are typical of stocking systems employed by many small commercial and non-commercial cattle enterprises in the lower south. At these spatial scales, cattle consistently used riparian habitats through all experimental periods at both farms (Fig. 3A, 4A); no significant change was detected in cattle distribution evenness for grassland habitats or the whole landscape (Fig. 3B, 4B) in response to alternative water alone or in combination with the shade structure at either farm landscape. This was likely a result of low movement costs to cattle for habitat selection choices since the distance traveled by cattle from any point was < $150 \mathrm{~m}$ to both riparian and wooded habitats within the studied landscape at Glendale Farms and $<260 \mathrm{~m}$ to both riparian and wooded habitats in the landscape at Summerford Farms. These distances are considerably shorter than maximum distances Hart et al. (1993) observed cattle to travel from water: $5.0 \mathrm{~km}$ on large, continuously-stocked pastures (207 ha) and 1.0 to $1.6 \mathrm{~km}$ on rotationally-stocked and small, continuously-stocked pastures (24 ha). For example, in July at Glendale Farms, cattle were observed to emerge from lying in a wooded riparian area to go directly to the water tank to drink. Therefore, comfort (relief from heat stress) appeared be a major criterion in habitat use decisions between 1100 and 1700 hours during the warm season at the relatively small spatial scales available for this study.

\section{Summary and Conclusions}

Habitat use by cattle was studied in two heterogeneous pasture landscapes ( 3.3 and $6.9 \mathrm{ha}$ ) in north-central Ala. that each included areas of woods and wooded riparian habitat as well as water and shade developments. Cattle preferred grassland areas, spent a significant amount of the daytime grazing, and rejected riparian areas during the cool season. Increased cattle presence was noted in woods and wooded riparian habitats during the warm season as heat stress likely caused marked changes in diurnal cattle behavior patterns and habitat use. Alternative water and shade sources failed to attract cattle away from riparian habitats for significant amounts of time; high-quality shade appeared to play a more important role than forage or water availability in increased use of riparian habitats by cattle during the warm season in these microclimates. Even though observations for this study were made in pastures at a relatively small landscape scales, they supported the observations made by Bryant (1982) in a 345-ha area of a grazing allotment in northeast Oregon. He concluded that pasture developments such as water and salt alone are not effective alternatives to reduction of cattle concentration in riparian habitats when other highly attractive landscape features such as preferred forage or more favorable microclimate were present. Bryant's (1982) suggestion for more effective reduction of ruminant livestock impacts on riparian habitats in large allotments of the northwest also appears to be a sound recommendation for the smaller grazed landscapes characteristic of the lower south: design of rotational stocking systems with riparian habitats included in separate subunits that are stocked for shorter periods of time than subunits with mainly open-pasture habitat.

\section{Literature Cited}

Bailey, D.W. and P.L. Sims. 1998. Association of food quality and locations by cattle. J. Range Manage. 51:2-8.
Bailey, D.W., L.R. Rittenhouse, R.H. Hart, D.M. Swift, and R.W. Richards. 1989. Association of relative food availabilities and locations by cattle. J. Range Manage. 42:480-482.

Ball, D.M., C.S. Hoveland, and G.D. Lacefield. 2002. Southern forages: Modern concepts for forage crop management. $3^{\text {rd }}$ ed. Graphic Communications, Lawrenceville, Ga.

Barrow, N.J. 1987. Return of nutrients by animals. p. 181-186. In: R. W. Snaydon (ed.) Managed grasslands. Elsevier, Oxford, England.

Blackshaw, J.K. and A.W. Blackshaw. 1994. Heat stress in cattle and the effect of shade on production and behavior: A review. Australian J. Exp. Agr.. 34:285-295.

Bryant, L.D. 1982. Response of livestock to riparian zone exclusion. J. Range Manage. 35:780-785.

Buckner, D.L. 1985. Point-intercept sampling in revegetation studies: Maximizing objectivity and repeatability. p.110-113. In: Proc. $2^{\text {nd }}$ Ann. Meeting. Bridging the gap between science, regulation, and the surface mining operation. Amer. Soc. Surface Mining and Reclamation, Princeton, W.Va.

Davis, L., M. Brittingham, L. Garber, and D. Rourke. 1991. Stream bank fencing: Better banks, clean streams. Penn State Coll. Agr. Ext. Circ. No. 397. University Park, Penn.

Godwin, D.C. and J.R. Miner. 1996. The potential of off-stream livestock watering to reduce water quality impacts. Bioresour. Technol. 58:285-290.

Hahn, G.L. 1999. Dynamic responses of cattle to thermal heat loads. J. Anim. Sci. 77 Suppl. 2/J. Dairy Sci. 82 Suppl. 2:10-20.

Hart, R.H., J. Bissio, M.J. Samuel, and J.W. Waggoner Jr. 1993. Grazing systems, pasture size, and cattle grazing behavior, distribution and gains. J. Range Manage. 46:61-67.

Howell, J.M., M.S. Coyne, and P. Cornelius. 1995. Fecal bacteria in agricultural waters of the bluegrass region of Kentucky. J. Environ. Qual. 24:411-419.

Howery, L.D., F.D. Provenza, R.E. Banner, and C.B. Scott. 1998. Social and environmental factors influence cattle distribution on rangeland. Appl. Anim. Behav. Sci. 55:231-244.

Ittner, N.R., C.F. Kelly, and H.R. Guilbert. 1951. Water consumption of Hereford and Brahman cattle and the effect of cooled drinking water in a hot climate. J. Anim. Sci. 10:742-751.

Johnson, D.H. 1980. The comparison of usage and availability measurements for evaluating resource preference. Ecol. 61:65-71.

Kauffman, J.B. and W.C. Krueger. 1984. Livestock impacts on riparian ecosystems and streamside management implications: A review. J. Range Manage. 37:430-438.

Levin, S.A. 1992. The problem of pattern and scale in ecology. Ecol. 73:1943-1967.

Mader, T.L., L.R. Fell, and M.J. McPhee. 1997. Behaviour response of non-Brahman cattle to shade in commercial feedlots. p. 795-802. In: Livestock environment 5, 
Volume 2. Proceedings of the fifth international symposium, Bloomington, Minn., USA, 29-31 May, 1997. American Society of Agricultural Engineers (ASAE), St. Joseph, Mich., USA.

Martin, J.H., Jr. 1997. The Clean Water Act and animal agriculture. J. Environ. Qual. 26:1198-1203.

Miner, J.R., J.C. Buckhouse, and J.A. Moore. 1992. Will a water trough reduce the amount of time hay-fed livestock spend in the stream (and therefore improve water quality)? Rangelands 14:35-38.

Mysterud, A. and R.A. Ims. 1998. Functional responses in habitat use: availability influences relative use in trade-off situations. Ecol. 79:1435-1441.

Mysterud, A., P.K. Larsen, R.A. Ims, and E. Østbye. 1999. Habitat selection by roe deer and sheep: does habitat ranking reflect resource availability? Can. J. Zool. 77:776-783.

Natural Resources Conservation Service. 1999. Heavy use area protection, NRCS Ala. Conservation Practice Standard Code 561.

Natural Resources Conservation Service. 2002. Livestock shade structure, NRCS Ala. Conservation Practice Standard Code 717.
Pell, A.N. 1997. Manure and microbes: public and animal health problem? J. Dairy Sci. 80:2673-2681.

Platts, W.S. 1991. Livestock grazing, p. 389-423. In: W. R. Meehan (ed.) Influences of forest and rangeland management on Salmonid fishes and their habitats. Amer. Fish. Soc. Spec. Pub. 19. Bethesda, Md.

Rouda, R.R., D.M. Anderson, J.D. Wallace, and L.W. Murray. 1994. Free-ranging cattle water consumption in south-central New Mexico. Appl. Anim. Behav. Sci. 39:29-38.

Senft, R.L., M.B. Coughenour, D.W. Bailey, L.R. Rittenhouse, O.E. Sala, and D.M. Swift. 1987. Large herbivore foraging and ecological hierarchies. Biosci. 37:789-799.

Sheffield, R.E., S. Mostaghimi, D.H. Vaughan, E.R. Collins Jr., and V.G. Allen. 1997. Off-stream water sources for grazing cattle as a stream bank stabilization and water quality BMP. Trans. ASAE 40:595-604.

Smith, M.A., J. D. Rodgers, J. L. Dodd, and Q. D. Skinner. 1992. Habitat selection by cattle along an ephemeral channel. J. Range Manage. 45:385-390.
Smolen, M.D., G.D. Jennings, and R.L. Huffman. 1990. Impact of nonpoint sources of pollution on aquatic systems: Agricultural land uses. In: Nonpoint Source Impact Assessment, Rep. 90-5. Water Environ. Res. Found. Alexandria, Virg.

Southwood, T.R.E. 1977. Habitat, the templet for ecological strategies? J. Anim. Ecol. 46:337-365.

Trimble, S.W. and A.C. Mendel. 1995. The cow as a geomorphic agent: A critical review. Geomorphology 13:233-253.

Turner, M.G., V.H. Dale, and R.H. Gardner. 1989. Predicting across scales: theory development and testing. Landscape Ecol. 3:245-252.

Van Horne, B. 1983. Density as a misleading indicator of habitat quality. J. Wildl. Manage. 47:893-901.

West, J. W. 1999. Nutritional Strategies for managing the heat-stressed dairy cow. J. Anim. Sci. 77 Suppl. 2/J. Dairy Sci. 82 Suppl. 2:20-35.

Zuo, H. 2001. Cattle behavior and impacts on streamwater quality. Ph.D. Diss., Auburn Univ., Ala.

Zuo, H. and M.S. Miller-Goodman. 2003. An index for description of cattle distribution patterns in grazed landscapes. J. Range Manage. 56:146-151. 